\title{
Article
}

\section{How important is the physical workplace to engagement and productivity?}

Smith, Andrew James

Available at http://clok.uclan.ac.uk/3077/

Smith, Andrew James (2011) How important is the physical workplace to engagement and productivity? Journal of Facilities Management, 9 (2). ISSN $1472-5967$

It is advisable to refer to the publisher's version if you intend to cite from the work.

For more information about UCLan's research in this area go to

http://www.uclan.ac.uk/researchgroups/ and search for <name of research Group>.

For information about Research generally at UCLan please go to

http://www.uclan.ac.uk/research/

All outputs in CLoK are protected by Intellectual Property Rights law, including Copyright law. Copyright, IPR and Moral Rights for the works on this site are retained by the individual authors and/or other copyright owners. Terms and conditions for use of this material are defined in the policies page.

\section{CLoK}

Central Lancashire online Knowledge www.clok.uclan.ac.uk

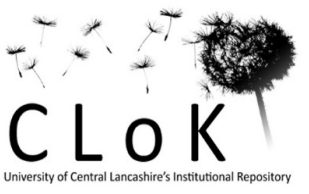


This article was originally published by Emerald at

Andrew Smith, (2011) "How important is the physical workplace to engagement and productivity?", Journal of Facilities Management, Vol. 9 Iss: 2, pp. -

http://www.emeraldinsight.com/journals.htm?issn=14725967\&volume $=9 \&$ issue $=2 \&$ articleid $=1923930 \&$ show $=$ html

Full metadata for this item is available in the University of Central Lancashire Research Repository http://CLoK/uclan.ac.uk

Please use this identifier to cite or link to this item http://clok.uclan.ac.uk/2932

Full copyright subsists in this work and remains with the publisher. 


\section{How important is the physical workplace to engagement and productivity?}

Work engagement is a relatively recent concept, research into which has only recently begun to emerge. Engagement has been described as a positive, fulfilling state of work related wellbeing, regarded by some as the antipode of burnout (Bakker et al., 2008). Engaged employees are highly energetic (vigour), feel pride and enthusiasm (dedication) and are able to focus completely on the task (absorption) (Wildermuth and Pauken, 2008). Vigour is characterised by high energy levels and mental resilience; dedication refers to being strongly involved in work and experiencing a sense of significance, enthusiasm and challenge, while absorption is characterised by being fully concentrated and happily engrossed, whereby time passes quickly (Bakker and Demerouti, 2007).

Research linking engagement to job performance has now begun to emerge and, while in its infancy, the published studies suggest a positive correlation between engagement and performance. A strategic facet of facilities management is to assist businesses to operate in an efficient and profitable manner and FM, therefore, could have a position at the forefront of engagement research.

According to Bakker et al. (2008), it has consistently been shown that job resources are positively associated with work engagement. These resources include factors such as social support from colleagues and supervisors, performance feedback, skill variety, autonomy and learning opportunities.

Job resources are physical, psychological, social or organisational aspects of the job that are functional in achieving work goals or reduce job demands and the associated physiological and psychological costs, or stimulate personal growth, learning and development (Bakker and Demerouti, 2007; Schaufeli and Bakker, 2004).

Therefore, job resources may be an intrinsic motivator in that they fulfil basic human needs such as autonomy, relatedness and competence (Bakker et al., 2008). An extrinsic motivational role may also be played by job resources because work environments offering many resources foster willingness to dedicate effort and abilities, increasing the likelihood of tasks being completed successfully and that work goals will be attained (Bakker et al., 2008).

Bakker and Demerouti (2007) highlight that whether through the satisfaction of basic needs or through achievement of work goals, the presence of job resources leads to engagement, while their absence evokes a cynical attitude towards work. Therefore, a favourable physical working environment could be a key job resource, helping to facilitate engagement.

Literature on the relationship between engagement and performance is relatively scarce. However, results of several studies look promising (Bakker et al., 2008). Engaged workers tend to perform better (Bakker et al., 2008), give their all to their jobs and are willing to go the extra mile to achieve success (Wildermuth and Pauken, 2008).

According to Bakker et al. (2008), there are four reasons why engaged workers perform better. Engaged employees often experience positive emotions including happiness, joy and enthusiasm; they experience better health (physical and psychological); they create their own 
job and personal resources (e.g. support from others); and they transfer their engagement to others.

Positive emotions broaden the thought-action repertoire, performance is facilitated by good health as individuals can use all their physical and mental resources and employees who create their own resources are able to deal better with job demands and to achieve work goals (Bakker et al., 2008). Further to this they make the point that performance, in most organisations, is the result of the combined efforts of individual employees. Therefore, it is conceivable that the crossover of engagement among members of the same work team increases performance.

Most researchers have not made the distinction between in-role and extra-role performance, although this is considered by Bakker et al. (2004). They define in-role performance as officially required outcomes and behaviours that directly serve organisational goals, including meeting organisational objectives and effective functioning. Additionally, employees may display extra-role activities, defined as discretionary behaviours, believed to directly promote the effective functioning of an organisation without necessarily directly influencing an individual's target productivity. Examples given are willingness to help colleagues who have heavy workloads or avoidance of problems with colleagues.

Bakker et al. (2004) demonstrated that engaged employees received higher ratings from their colleagues on in-role and extra-role performance, which is an indication that engaged employees perform well (Bakker et al., 2008).

Is it possible or likely then that the physical workplace has a significant impact upon engagement and hence, work performance? It could be argued that the workplace is an intrinsic job factor and constitutes a resource, which would be positively associated with work engagement. As one of many contributory resources, a high quality working environment should contribute to an engaged, and hence, productive workforce. In the same way, a poor quality working environment could be a detracting factor from an engaged workforce.

Research into these linkages is required in this developing field and it would appear that there is an opportunity for the FM profession to make a major strategic contribution.

\section{Andrew Smith}

\section{References}

Bakker, A.B., Demerouti, E., Verbeke, W. (2004) "Using the Job Demands-Resources model to predict burnout and performance.” Human Resource Management, Vol. 43, No. 1, pp. 83104.

Bakker, A.B., Demerouti, E. (2007) “The Job Demands-Resources model: state of the art." Journal of Managerial Psychology, Vol. 22, No. 3, pp. 309 - 328. 
Bakker, A.B., Schaufeli, W.B., Leiter, M.P., Taris, T.W. (2008) "Work engagement: An emerging concept in occupational health psychology.” Work \& Stress, Vol. 22, No. 3, pp. 187 $-200$.

Schaufeli, W.B., Bakker, A.B. (2004) "Job demands, job resources, and their relationship with burnout and engagement: a multi-sample study.” Journal of Organizational Behavior, Vol. 25, pp. $293-315$.

Wildermuth, C., Pauken, P.D. (2008) "A perfect match: decoding employee engagement part 1: Engaging cultures and leaders.” Industrial and Commercial Training, Vol. 40, No. 3, pp. $122-128$. 